\title{
Innovation of University Teaching Methods towards "Maximizing Benefits" of Students in Vietnam
}

\author{
Nguyen Van Hiep ${ }^{1, *}$, Pham Ngoc Tram ${ }^{2}$ \\ ${ }^{1}$ Thu Dau Mot University, Binh Duong 75109, Vietnam \\ ${ }^{2}$ Faculty of Social Sciences and Humanities, Thu Dau Mot University, Binh Duong 75109, Vietnam
}

Received September 9, 2020; Revised December 1, 2020; Accepted December 13, 2020

\begin{abstract}
Cite This Paper in the following Citation Styles
(a): [1] Nguyen Van Hiep, Pham Ngoc Tram, "Innovation of University Teaching Methods towards "Maximizing Benefits" of Students in Vietnam," Universal Journal of Educational Research, Vol. 8, No. 12B, pp. 8255-8261, 2020. DOI: 10.13189/ujer.2020.082630.
\end{abstract}

(b): Nguyen Van Hiep, Pham Ngoc Tram (2020). Innovation of University Teaching Methods towards "Maximizing Benefits" of Students in Vietnam. Universal Journal of Educational Research, 8(12B), 8255-8261. DOI: 10.13189/ujer.2020.082630.

Copyright $\bigcirc 2020$ by authors, all rights reserved. Authors agree that this article remains permanently open access under the terms of the Creative Commons Attribution License 4.0 International License

\begin{abstract}
The innovation of university teaching methods is an objective requirement in improving the quality of higher education in Vietnam, in line with world development trends; meeting the requirements of the labor market in the context of deepening international innovation and integration. The university teaching method innovation not only aims to train successful individuals and responsible citizens but also make learners realize the benefits of learning so that they feel confident in understanding a wide range of issues and experiences in university or real life, regardless of any specialization. "Maximizing benefits" is an important argument of rational choice theory initiated in 1961 by the American sociologist George Homans (1910-1989). The rational choice theory states that people for the benefit of people will actively maximize their advantage in all situations, and try to minimize losses. So, each individual must calculate and consider making the most reasonable decision of his own. On the basis of providing an overview of the problem "Maximizing benefits" of the theory of reasonable choice, this article will apply this point of view to innovate university teaching methods in the context of Vietnam's deepening innovation and integration.
\end{abstract}

Keywords Innovation, University Teaching Methods, Maximizing Benefits, Rational Choice Theory

\section{Introduction}

The innovation of university teaching methods is an objective requirement in improving the quality of higher education in Vietnam, in line with world development trends; meeting the requirements of the labor market in the context of deepening international innovation and integration.

The innovation of Vietnam university teaching methods is not the abandonment of all traditional teaching methods but must inherit and create based on the value selection of old methods, absorb and learn new teaching methods, and modernization aims at training capable and dynamic individuals to contribute to the overall development of the country. The aim of university teaching method innovation not only trains successful individuals and responsible citizens but also makes learners realize the benefits of learning so that they feel confident in understanding a wide range of issues and experiences in university or real life, regardless of any specialization.

"Maximizing benefits" is an important argument of rational choice theory initiated in 1961 by the American sociologist George Homans (1910-1989). The rational choice theory states that people for the benefit of people will actively maximize their advantage in all situations, and try to minimize losses. So, each individual must calculate and consider to make the most reasonable decision of his own. Based on providing an overview of the problem "Maximizing benefits" of the theory of reasonable choice, this article will apply this point of view 
to the innovation of university teaching methods in the context of Vietnam's deepening innovation and integration by emphasizing the advantages of the "Maximizing benefits" approach of students and drawing several implications to the innovation of university teaching methods in Vietnam today.

The paper is structured as follows: Section 2 is about literature review of "Maximizing benefits". Section 3 presents the practical issues of "Maximizing benefits" of learners in Vietnam. Section 4 concludes.

\section{2. "Maximizing Benefits": A Literature Review}

The innovation of university teaching methods is studied from many different angles by scientists in many countries. A typical example is the Programmer for International Student Assessment (PISA) (OECD, 2013), which is a program of surveying, researching, and evaluating teaching and learning in Germany. The PISA research has shown shortcomings of German education in general, and humanities and social sciences teaching in particular. And this study is likened to a "PISA shock", which has become a kick-in for German education reform since 2000, putting a heavy burden on the higher education role in the teaching orientation toward "capacity building" (OECD, 2005).

Teaching innovation in India also focuses on capacity development towards "maximizing benefits" of learners. The National Curriculum Framework of India (National Curriculum Framework) issued in 2005 (National Council of Educational Research and Training, 2005) advocates 5 principles: (1) Connecting knowledge with life outside the school; (2) Ensuring that the teaching is not confined to the rigid methods; (3) Enriching the learning program beyond what is in the textbook; (4) Making exams, tests flexible and integrated with the classroom environment; and (5) Most importantly, nurturing of identity expressed through caring for the country's democratic political regimes.

In order to "maximize benefits" of learners, the National Council of Educational Research and Training (2005) focuses on (1) Encouragements to think and help learners develop problem-solving skills; (2) Life skills: critical thinking, effective communication, creativity, civic responsibility, self-awareness, emotional restraint, interpersonal relationships, empathy, observation; (3) Problem-solving skills; (4) Value-based questions.

In Pakistan, since 2002, higher education emerged as a crucial part of the social planning, and the Pakistan government has improved the Vision 2020 in which the role of higher education in economic development has been highlighted (Noor, Muhammad, \& Sania, 2020).

In addition, several other authors also propose "maximizing benefits" of learners in the process of innovating educational methods, in general, for innovating higher education methods, in particular. Wallace and Wolf (1999) argue that in a society the physical and spiritual values cannot meet human needs, so human behavior is governed by a desire to reasonably maximize their interests. Andersson (2016) studieds decision-making and risk-taking in academic environments, analyzed educational options, rationality, and explained how students make their educational choices. The author has highlighted the usefulness, "maximizing benefits" of the students in educational options. Shanks, Tunney, and McCarthy (2002) conduct a field survey in the education field about the learner's choice in the learning task. The research results have clarified many problems with "maximizing benefits" of learners. Vanberg (2004) outlines some principles in the method of rational principle approach and reasonable hypothesis, and emphasizes the "Maximizing benefits" behavior of human; at the same time, so as to solve the problem, we must capture "Maximizing benefits" behavior to avoid possible mistakes. Pereverzeva, Kats, Ovsyannikova, Aksenova, and Yushchenko (2020) try to classify types of innovative teaching technologies related to the development of musical and acting abilities in Russia and find that the school comprehensive development implies not only the development of basic skills and abilities, but also the formation of artistic taste and musical and acting skills.

Regarding innovation of university teaching methods in Vietnam, several studies indicate many important aspects and propose various approaches to increase the quality of tertiary education, such as building teaching and learning strategies through teaching innovation and learners' creativity (Van, 2020), university lecturers (Song and Le (2018), Luong, Tran, and Tran (2018)), maximizing classroom interaction (Lap \& Thy, 2017), English Language Policy Reforms (Bui \& Nguyen, 2016), contextualized culture integration (Allison \& Do, 2015), obtaining long-term benefits from short-term study-abroad programs (Kamdar and Lewis (2015), McCornac (2012)), university reform agendas (T. K. Q. Nguyen, 2011), and teaching and research activities (P. N. Nguyen \& Tilak, 2008).

In Vietnam, since the Central Committee of the Communist Party of Vietnam issued Resolution 29-NQ/TW dated November 4, 2013, on "Fundamental, comprehensive reform of education and training, to meet the demand for industrialization and modernization in the context of a socialist-oriented market economy and international integration" (Communist Party of Vietnam, 2013). According to this Resolution, for higher education, to focus on training highly qualified human resources, fostering talents, developing the quality and capacity of self-study, enriching knowledge, and creativity of learners. To perfect the network of higher education institutions, the professional structure and training qualifications suitable to the national human resource development 
planning; in which, there are several schools and specializations disciplines of regional and international level. Diversifying training institutions to suit the development needs of technologies, fields, and occupations; requirements for national construction, defense, and international integration. In the field of continuing education, ensuring opportunities for everyone, especially in rural and disadvantaged areas, policy beneficiaries can learn to improve their knowledge, qualifications, professional skills, and life quality; create favorable conditions for workers to change jobs; ensure sustainable literacy eradication; complete the network of continuing education institutions and diversified and flexible forms of learning and practice; attaching importance to self-study and distance education. The resolution also outlines a number of tasks and solutions in Vietnam's education reform: Basically renovate the exam forms and methods, ensure honesty and objectivity of testing and evaluating the results of education and training; complete the national education system towards an open education system, lifelong learning and building a learning society; fundamentally renew the education and training management, ensuring democracy and unity; increased autonomy and social responsibility of education and training institutions; attaching importance to quality management, developing the contingent of teachers and administrators, meeting the requirements of education and training innovation, reforming policies, financial mechanisms, mobilizing the participation of the whole society; improve the efficiency of investment to develop education and training to improve the quality and effectiveness of science and technology research and application, especially educational science and management science, actively integrate and improve high efficiency of international cooperation in education and training.

In general, works emphasize the beneficial role of learners, requiring teachers to create learning opportunities through diverse activities, stimulating students to explore, apply and analyze and evaluate ideas; active teaching methods, towards promoting the initiative of learners; build motivation to learn and form lifelong learning habits.

\section{Practical Issues of "Maximizing Benefits" of Learners in Vietnam}

\section{1. "Maximizing Benefits" of Learners: Practical Issues}

Benefits are one of the important driving forces that directly promote human actions to satisfy individual, family, collective, ethnic and social needs. The benefits become the ideological engine of purposeful practical activity, manifesting in both the physical and mental fields.
In which, the biggest benefit is the basic human needs, including safety; stable economic conditions; feeling of ownership; being admitted; be able to secure other people's lives.

To satisfy the benefits, people are constantly working, learning, and looking for opportunities. In innovating teaching methods, teachers must pay attention to the interests of learners, and identifying the learners' interests is important and justifiable. Thus, students will learn better if they feel that the teacher has understood them. Students tend to assume that those who understand them are often "smart" and sympathetic to them, so their opinions are worth listening to. Therefore, in innovating teaching methods, teachers should clearly understand the interests of learners and acknowledge their interests as part of the teaching process. As a teacher, if you want a listening learner to approach your lecture, state the benefits and reasons first, and then proceed with the other content in sequence.

"Maximizing benefits" of learners is a law that reflects the wishes of people in educational choices. According to the law of "maximizing benefits" in education, learners have to spend an expense, including money, effort, and passion to study a certain industry to bring their benefits. This is the basis for the school, university lecturers to innovate teaching methods, and also the principles of dealing with learners.

"Maximizing benefits" of learners in educational options has have been reflected in rational choice theory (Rational Choice Theory) in the 1960s by Homans (1961). And in the 1970s, several other scientists such as Blau (1964), Coleman (1973), Cook and Emerson (1978), and Knottnerus and Guan (1997) have extended and contributed to the development of this theory. This theory assumes that all human acts stem from a certain purpose as McNabb (2015, p. 31) said:

"Faced with options they already know about the cost and benefits of each option; people will act in a way that gives them the most benefit."

In that sense, people try to proactively maximize their advantage in all situations and minimize losses at the highest level. Benefits govern student behavior and students will act under the law of interest. Therefore, teaching method innovation must be set in the direction of controlling the behavior of all parts and individuals to meet the goal of "maximizing benefits" of learners consider this as a principle in innovating university teaching methods and reasonably solving other social problems in schools.

Andersson (2016) stresses that in contemporary society, each person has her/his own most crucial decisions about how to choose education to determine their own life. Because education does not just give people a way livelihood, income source but also aspiration, honor, towards the true values of humans in society and make people more responsible for themselves. Andersson (2016) 
further adds that the decision is done in highly individualized societies and that educational decision is based on individual interest. For this sake, learners will decide what, when, how, and which school to study, etc... to bring them the most benefit. That requires schools to build principles of behavior with learners, according to the principle of maximizing benefits. In modern education, "maximizing benefits" is considered as the operating principle and the governance principle governing the behavior of all departments and individuals, to meet the goal of maximizing the interests of learners.

One of the leading solutions to "maximizing benefits" for university students is to innovate teaching methods. Higher education Vietnam has maintained for too long a rigid traditional teaching method, which is teacher-centered, lectures based on curriculum, and has not paid adequate attention to the interests of learners. Not only in Vietnam, university teaching with the lecturer-centered presentation method has existed for a long time in the history of many countries (Bonwell \& Eison, 1991).

With presentation teaching methods, teachers force students to listen, to think in the way of teachers; faculty decides and students must follow; students have no choice. Although traditional teaching methods give teachers the ability to show and impart knowledge, aiming to make students understand and remember knowledge, traditional teaching methods that pay little attention to developing thinking, training skills, and training attitudes for learners. It leads to the situation that most of the students learn passively, and graduated students do not respond well to the job requirements, and do not satisfactorily solve the interests of learners (V. H. Nguyen \& Pham, 2020).

The scientific basis of traditional teaching methods is that when information and knowledge reach the learners' brains, they are converted and stored in memory, then the information can then be retrieved as needed. In practice, there are still teachers who have applied the presentation method quite successfully. However, traditional teaching methods such as "teachers speak - students listen", "teachers read - student rewrite", "teachers show - student rewrite" have revealed some limitations, namely: it discourages the active role of learners; learners become passive in learning activities, and this affects their learning ability and concentration; it discourages multidimensional information exchange; lecturers communicate in one-way and unable to control the time duration that learners spend on studying and deeply memorizing the content presented. In order to study well, learners must listen, take notes, try to remember to repeat the knowledge taught because the exams, the final graduation often require recalling memory; Learners must use memory a lot, which leads to fatigue, stress, and pressure (V. H. Nguyen \& Pham, 2020).

In thinking, regarding traditional teaching methods, most students and some university lecturers still consider the university as a "secondary" level, or "post-secondary" level, and maintain a way of learning, teaching one-way knowledge transmission; learn a "cram"; "follow" the curriculum, and be afraid of "burning" the lesson plan. Teachers give "what they have", regardless of whether students "need" or not; the learners are forced to "accept". As a result, the quality of Vietnam's higher education is deteriorating, not qualified to integrate into the regional and international labor market (V. H. Nguyen \& Pham, 2020). It is difficult for a student graduating from university in Vietnam to work in countries with relatively high incomes, unless Vietnam university graduates update more with their knowledge, skills, and this takes a lot of time, effort, and investment.

While the application of teaching methods and forms of teaching organization of universities in the world is often very flexible, based on the spirit of promoting the role of learners, creating maximum conditions for self-study, self-research, the current popular conception of Vietnamese universities is to equip learners with as much knowledge as possible so that they can have a solid foundation upon graduation. Thus, so the role and position of students are not concerned. Teaching methods and forms are still quite out of date. The innovation of teaching methods in universities is sometimes only superficial, the realization that education must be creative, responsible reflected in the lack of attention paid to methodology and curriculum improvements (Phạm Công Nhất, 2014).

\subsection{Some Implications for "Maximizing Benefits" of Learners in Vietnam}

By "maximizing benefits", we mean, on the one hand, we do not remove all the values of the old method, but we select and inherit the traditional method, and on the other hand, we apply the value of new methods to the innovation of university teaching methods. By doing so, we can make Vietnam's university teaching methods flexible, diversified, rich, updated with methods and degrees of advanced universities in the world.

What to do and how to help learners cope with risks, aiming to "Maximize their benefits" in the university process in the context of Vietnam?

According to Andersson (2016), teachers must master the learners' disciplines, grasp the rapidly changing society and context, train them in basic skills and knowledge and creative thinking, the ability to adapt when the job changes continuously to avoid the risk of rejection, "need to convince them to accept risks, overcome challenges, and believe in a bright future". In order to "maximize benefits" of learners, teachers should not only focus on teaching students what they have but must teach students to create new things. In which, it is necessary to teach how to learn, how to self-study, how to research, how to solve practical situations with learning goals to 
compete, to work. Depending on the subject, teachers must have a method of orientation, creating excitement for learners.

It is common in Vietnamese universities, where teachers do not fully provide the requirements and value of the subject, especially the non-specialized subjects of students. In practice, most lecturers of these subjects, upon request, only clarify the subject, method, and meaning of the subject; while the benefits of each subject to the disciplines are almost "open". Even for some new specializations, it is unlikely that (some) lecturers in general subjects of political theory can understand, especially new specializations in Vietnam such as logistics, international certification integration audit, marketing - communication; ensuring food quality and safety; robot and artificial intelligence; textile materials, ...

Thus, "maximizing benefits" of learners in innovating university teaching methods in Vietnam is clarifying the benefits of beneficiaries for each subject. When this problem is solved well, other contents can be conveyed well to learners, creating conditions for improving the quality of university teaching. And in the current university context with many rich options, teachers not only have to know "to teach" but also to know "to persuade". Know "to teach": teach correctly, with appropriate progressive methods. Know "to persuade": is an art of comfort; gently persuade and entice learners through the benefits of the subject, according to the motto "maximizing benefits" of learners.

"Maximizing benefits" of learners, must focus on learning rather than teaching, making learners express their thoughts and desires, on the basis of which it creates conditions for them to become an active member, actively participating in discussing subjects related to the subject. We should not be confined under the "curriculum" - is the content framework of predefined - which must develop lessons by expanding their thinking, apply the methods, approaches differ solving problems. As a teacher, do not be impatient with the fear of "burning lesson plans", but interactively makes the learners' perception to flourish and develop. According to the logic of development, the learner will "enlighten" - high awareness - of the problem under discussion. Or in other words, when the learner got the point, you are successful, without having to describe the problem in order, concept, origin, development, ...

With any subject taught in the university, most of them have outlines and references, many subjects also have the full textbook, even many textbooks of many different authors. The knowledge presented in the available documents is objective, rich, diverse, and multidimensional. It is this richness and diversity that makes teachers and students more inclined to try to remember facts and problems than to explore, explore, criticize, contribute, and create knowledge based on their own experience. Thus, the middle-ground player intangibly destroys the "interests" of learners, making them confused in the amount of knowledge of the subject, by the "cramming" of the teacher. And each subject of each instructor continues the process of "cramming" subject knowledge in a hasty, regular way, without creating connection and integration of the subjects.

Therefore, to innovate university teaching methods in the direction of promoting "maximizing benefits" of learners, teachers must lead suggestions, create conditions for learners to learn, explore, criticize, contribute and create knowledge based on accumulated knowledge, methods, and experience. "Maximizing benefits" of learners is to limit the provision of superior knowledge with little practice; promote the activeness and initiative of students; appreciate learners' appreciation, focus on their true development.

"Maximizing the benefits" of learners is also the fruitful promotion of a long, hard-working process, making students proud of their choices, even though they know that college is not. the destination of human life. A dynamic, professional learning environment at university will help students achieve their desired goals, "a deeper understanding of the specialized knowledge and personal and higher career skills to help them adapt. with the rapidly changing needs of life and work " (Nguyễn Văn Hiệp, 2019). In order to "maximize the benefits" of learners, innovating university teaching methods should "shift from teaching focusing on transmitting and remembering knowledge to a form of deeper education, focusing on application. and mastering a variety of skills, such as those that help graduates think critically and evaluate information, solve complex practical problems, and create products, processes, and systems. a new tradition, collaborate and work effectively with people, work with and create digital media, adapt to cultural differences, and life-long self-study” (Nguyễn Văn Hiệp, 2019).

\section{Conclusions}

The innovation of university teaching methods is an objective requirement in improving the quality of higher education in Vietnam, in line with world development trends; meeting the requirements of the labor market in the context of deepening international innovation and integration. The innovation of Vietnam university teaching methods is not the abandonment of all traditional teaching methods but must inherit and create based on the value selection of old methods, absorb and learn new teaching methods, and modernization aims at training capable and dynamic individuals to contribute to the overall development of the country. In this study, we want to emphasize the advantages of the "Maximizing benefits" approach of students and drawing several implications to the innovation of university teaching methods in Vietnam today. 
The innovation of university teaching methods is both an objective requirement of reality and a driving force for development. Innovating teaching methods is not a complete abandonment of old teaching methods, but must selectively, inherit traditional and modern teaching methods to meet social needs, and to train students. Students have comprehensive professional knowledge, have a firm grasp of principles and natural-social laws, have basic practical skills, ability to work independently, creatively, and solve problems within the trained industry. With the approach of "Maximizing benefits" of learners in innovating university teaching methods in Vietnam, it requires lecturers to renew their thinking about teaching how to learn, taking learners as the center to promote student initiative. The role of the teacher in the dynamic and intelligent university environment of the twenty-first century is not only the imparting knowledge but also as a guide, problem-raising person, and maximizer of self-study and independent thinking of students with the support of information technology, communication, and modern equipment and teaching facilities.

\section{REFERENCES}

[1] Allison, E. S., \& Do, T. (2015). Contextualized Culture Integration through Project-Based Learning in EFL Classrooms in Vietnam. Journal of NELTA, 20(1-2), 5-15.

[2] Andersson, T. (2016). Rationality in educational choice: A study on decision-making and risk-taking in academic settings. Retrieved from https://www.diva-portal.org/smash /record.jsf?pid=diva2\%3A945136\&dswid=3518

[3] Blau, P. M. (1964). Exchange and power in social life. New York: John Wiley and Sons. In: Inc.

[4] Bonwell, C. C., \& Eison, J. A. (1991). Active Learning: Creating Excitement in the Classroom. 1991 ASHE-ERIC Higher Education Reports: ERIC.

[5] Bui, T. T. N., \& Nguyen, H. T. M. (2016). Standardizing English for educational and socio-economic betterment-a critical analysis of English language policy reforms in Vietnam. In English language education policy in Asia (pp. 363-388): Springer.

[6] Coleman, J. (1973). The Mathematics of Collective Action. London: Heinemann.

[7] Communist Party of Vietnam. (2013). Resolution No. 29 / NQ-TW of the Central Executive Committee, Session XI. Hanoi: National Political Publishing House.

[8] Cook, K. S., \& Emerson, R. M. (1978). Power, equity and commitment in exchange networks. American sociological review, 721-739.

[9] Homans, G. C. (1961). Social behavior: Its elementary forms. Social Behavior, 119(3), 488-531.

[10] Kamdar, N., \& Lewis, T. (2015). Deriving long-term benefits from short-term study-abroad programs. Journal of
Management \& Engineering Integration, 7(2), 1.

[11] Knottnerus, J. D., \& Guan, J. (1997). The Works of Peter M. Blau: Analytical Strategies, Developments and Assumptions. Sociological Perspectives, 40(1), 109-128. doi:10.2307/138 9495

[12] Lap, T. Q., \& Thy, H. V. U. (2017). EFL Teachers' Challenges in Maximizing Classroom Interaction. Studies in English Language Teaching, 5(4), 695-709.

[13] Luong, T. L., Tran, X. L., \& Tran, V. N. (2018). Work motivation and performance of administrators in selected private universities of Ho Chi Minh City, Vietnam. European Journal of Social Sciences Studies.

[14] McCornac, D. C. (2012). The challenge of corruption in higher education: the case of Vietnam. Asian Education and Development Studies.

[15] McNabb, D. E. (2015). Research Methods for Political Science. New York, London: M.E Sharpe Armonk

[16] National Council of Educational Research and Training. (2005). National Curriculum Framework.

[17] Nguyen, P. N., \& Tilak, J. B. G. (2008). The Teaching/Learning and Research Nexus in Higher Education. Paper presented at the Competition, Collaboration and Change in the Academic Profession: Shaping Higher Education's Contribution to Knowledge and Research. Quezon City, Philippines: UNESCO Forum on Higher Education, Research and Knowledge and De La Salle University-Manila.

[18] Nguyen, T. K. Q. (2011). Globalization and higher education in Vietnam. Journal of Interdisciplinary Studies, 23(1/2), 117.

[19] Nguyễn Văn Hiệp. (2019). Dạy và học sâu săc theo triết lý giáo dục hòa hợp tích cực (In-depth teaching and learning in accordance to the philosophy of a positive integration education). Thành phố Hồ Chí Minh: Nhà xuất bản Đại học quốc gia.

[20] Nguyen, V. H., \& Pham, N. T. (2020). Innovation in Vietnamese higher education teaching methods - approach from rational choice theory. Universal Journal of Educational Research, 8(12A).

[21] Noor, F., Muhammad, I. A., \& Sania, Z. (2020). Higher Education Policy \& Research in Pakistan: Challenges in Transformation of the Society and the Way Forward. Universal Journal of Educational Research, 8(7), 2842 2852. doi:DOI: 10.13189/ujer.2020.080711

[22] OECD. (2005). Definition and Selection of Key Competencies-Executive Summary. http://www. deseco. admin. ch/bfs/deseco/en/index/02. html.

[23] OECD. (2013). PISA 2012: Ergebnisse im Fokus.

[24] Pereverzeva, M. V., Kats, M. L., Ovsyannikova, V. A., Aksenova, S. S., \& Yushchenko, N. S. (2020). Technology and Innovation in Schoolchildren Training: Development of Musical and Acting Skills. Universal Journal of Educational Research, 8(7), 2766 - 2771. DOI: 10.13189/ujer.2020.0807 03.

[25] Phạm Công Nhất. (2014). Đổi mới giáo dục đại học theo hướng hội nhập quốc tế ở nước ta hiện nay $(\mathrm{On}$ reform of 
higher education towards international integration in our country today). Retrieved from http://tapchicongsan.org.vn/ web/guest/chi-tiet-tim-kiem/-/2018/30373/\%C4\%91oi-moigiao-duc-\%C4\%91ai-hoc-theo-huong-hoi-nhap-quoc-te-o-n uoc-ta-hien-nay.aspx

[26] Shanks, D. R., Tunney, R. J., \& McCarthy, J. D. (2002). A re-examination of probability matching and rational choice. Journal of Behavioral Decision Making, 15(3), 233-250.

[27] Song, G., \& Le, T. H. A. (2018). Policy on Developing University Lecturers in Some Developed Countries in the World and the Experience Lessons for Vietnam. Paper presented at the 3rd International Conference on Judicial, Administrative and Humanitarian Problems of State
Structures and Economic Subjects (JAHP 2018).

[28] Van, V. H. (2020). Building strong teaching and learning strategies through teaching innovations and learners' creativity: A study of Vietnam Universities. International Journal of Education, 8(3), 498-510.

[29] Vanberg, V. J. (2004). The rationality postulate in economics: its ambiguity, its deficiency and its evolutionary alternative. Journal of Economic Methodology, 11(1), 1-29. doi:10.1080/1350178042000177987

[30] Wallace, R. A., \& Wolf, A. (1999). Contemporary Sociological Theory: Expanding the Classical Tradition: Prentice Hall. 